\title{
Land Use Change Implications for Large-scale Cultivation of Algae Feedstocks in the United States Gulf Coast
}

\author{
Robert M. Handler ${ }^{1 *}$, Rui Shi ${ }^{1,2}$, David R. Shonnard ${ }^{1,2}$ \\ ${ }^{1}$ Sustainable Futures Institute, Michigan Technological University, 1400 Townsend Drive, \\ Houghton, MI 49931-1295, USA \\ ${ }^{2}$ Department of Chemical Engineering, Michigan Technological University, 1400 Townsend Drive, \\ Houghton, MI 49931-1295, USA \\ *Corresponding author: 840 Dow Bldg, Michigan Tech, 1400 Townsend Drive, Houghton, MI \\ 49931, USA. Tel.: 906-487-3612. Email: rhandler@mtu.edu
}




\begin{abstract}
Algae is considered a promising future feedstock for biofuels. Although several studies have been conducted to assess the environmental impact of algae-based fuels, land use change is one area that is commonly overlooked in previous life cycle assessment studies. However, land use change can impact the life cycle greenhouse gas (GHG) emissions of algal biofuels when large tracts of land are converted to algal raceway cultivation systems. This study assesses the impacts of land use change through a variety of means. The Intergovernmental Panel on Climate Change (IPCC) Tier 1 methodology was utilized to assess potential emissions resulting from the conversion of potential algae facility sites in the U.S. Gulf Coast, consisting of grassland, cropland, and forestland in several management conditions. These emission values over a 20-year time horizon were combined with guidance on promising sites for algae raceway development to provide an estimate of industry-wide GHG emissions impacts due to direct land use change (LUC). Direct LUC impacts appear to be important, with average GHG emissions of between 4 and $8 \mathrm{~g} \mathrm{CO}_{2 \mathrm{eq}} / \mathrm{MJ}$ for grassland and cropland conversion, which is roughly $6.3 \%$ and $12.5 \%$ of the total GHG emission over the entire algae renewable diesel life cycle without considering the LUC. Emissions due to direct LUC could be even larger if previously forested lands are cleared, averaging $24.7 \mathrm{~g}$ $\mathrm{CO}_{2 \mathrm{eq}} / \mathrm{MJ}$ across a range of potential algae sites. This article details the methods, assumptions and initial LCA results for these land use change scenarios when considering the algae biofuels life cycle. Results from this LCA can help decision-makers recognize the importance of facility siting in overall environmental performance, and select locations of algae cultivation facilities to minimize direct LUC emissions.
\end{abstract}

\title{
Key words
}

Algae Biofuel, Life cycle Assessment, Land Use Change, IPCC, Soil Organic Carbon 


\section{Introduction}

Algae-based alternative fuels are viewed as a promising bioenergy pathway for many reasons, including high biomass growth rates, tolerance to brackish water, and the ability to be sited on marginal lands (Chisti, 2007; Mata et al., 2010). Questions persist, however, about the environmental and economic benefits of this immature industry (ANL et al., 2012). Life cycle assessment (LCA) studies have been conducted to determine the greenhouse gas emissions of the entire supply chain of algae-based fuels, and many different modeling assumptions have been used to characterize algae cultivation, harvesting, and downstream processing. One area of the fuel life cycle commonly overlooked in algae systems is the concept of land use change (LUC). Changes in land use patterns can lead to release of $\mathrm{CO}_{2}$ into the atmosphere from the decomposition or burning of above and belowground biomass, and from changes to the carbon content of soils in the system.

Among many algae cultivation configurations, there are two most particular common types of configurations for algae cultivation: the open pond (OP) system and horizontal tubular photo bioreactors (PBRs). Pulz (2001) conducted a comprehensive comparison of pros and cons of OP system and PBRs. Several scientific studies following Pulz's research are in general agreement that although PBRs may have higher lipid production, the OP algae cultivation system is preferable to PBR cultivation system in terms of energy consumption and GHG emissions, and is less expensive than PBRs because of the lower costs to build and operate (Chisti, 2007; Resurreccion et al., 2012). The preferable OP system infrastructure requires a large area of land for pond construction, with an estimation of 30 million acres of land requirement to meet US oil demand (Hannon et al., 2010). Therefore, a thorough investigation of the environmental impacts associated with algae biofuels should include an assessment of the consequence of the anticipated LUC activities that will take place over the life of the algae cultivation system. 
Land use change in other biomass feedstocks has been shown to be an important component of the life cycle fuel greenhouse gas (GHG) emissions of biofuels (Georgianna and Mayfield, 2012; Kim et al., 2009; Searchinger et al., 2008). This is the case whether the change in emissions is directly due to switching use of land (e.g., switching crops) (Clarens et al., 2011) or indirectly due to consequential changes in land use outside of the biofuel system from market forces linked to the biofuel production (Fritsche et al., 2010). One notable example of indirect land use change would be diversion of corn from food and animal feed to fuel ethanol production, which then may stimulate natural land types to converted to corn production (Haag and Mill, 1987). Although studies have been conducted to indicate the high variability of environmental impacts during cultivation of algae feedstocks (Carlsson et al., 2007; Chisti, 2007; Handler et al., 2012), little thought has been given to the emissions from converting land to algal cultivation (Brentner et al., 2011; Frank et al., 2011), or it has been assumed emissions are negligible compared to other life cycle stages (Clarens et al., 2011; Stephenson et al., 2010). Lardon (2009) estimated that land use of algae biodiesel is low compared to other biofuels, which roughly $1 / 6$ to rapeseed biodiesel and 1/10 to soybean derived diesel. The author concluded that this considerably low land use impact was a result of the high algae biomass yield, algae oil content, and oil production rate compared to other biomass feedstocks. This comparison of land use for different biofuels systems in Lardon (2009) is also an example of how traditional life cycle assessment has typically dealt with land use as primarily an issue of land occupation, thereby removing that land from other productive uses. Recent land use change studies attempt to evaluate the impact of land transformations and hold the new products being grown on the land accountable for those impacts.

A recent comprehensive government report authored by members of U.S. national laboratory research teams, including Argonne National Laboratory, Pacific Northwest National Laboratory, and the National Renewable Energy Laboratory, attempted to standardize assumptions regarding the current performance baseline in algae biofuels production to present an accurate picture of the environmental, economic, and resource implications of large scale algae production in the U.S. Gulf Coast (ANL et al., 
2012). In this study, the unit operations involved in producing renewable diesel (RD) from algae included open pond cultivation, dissolved air flotation harvesting, centrifugation for dewatering, solvent oil extraction followed by hydrotreatment to renewable diesel, without considering impacts due to land use change. Greenhouse gas emissions for the baseline scenario were $63.9 \mathrm{~g} \mathrm{CO}_{2 \mathrm{eq}} / \mathrm{MJ} \mathrm{RD}$, but emissions could vary by more than $5 \mathrm{~g} \mathrm{CO}_{2 \mathrm{eq}} / \mathrm{MJ} \mathrm{RD}$ depending on the growing seasons and in different regions.

In spite of the progress in understanding GHG emissions from algae-biofuel production systems, research on the environmental impacts of LUC emissions from algae cultivation remains lacking in the literature. The study reported here utilized methodology adopted by the Intergovernmental Panel on Climate Change (IPCC) to evaluate several scenarios (IPCC, 2006a) to quantify the range of potential GHG emissions due to direct LUC in algal cultivation systems. IPCC Tier 1 methodology was used to assess potential emissions resulting from conversion of U.S. Gulf Coast grassland, cropland and forestland in several management conditions. This assessment was enabled by the prior national laboratory (ANL et al., 2012) comprehensive report that evaluated promising sites for algae raceway development in the Gulf Coast region of the USA, and provided a detailed, geographically specific example of what a large scale algae industry might look like. The objective of this study was to provide a more comprehensive view of the life cycle GHG emissions that can be expected from large scale algae cultivation by quantifying direct LUC emissions (hereafter referred to simply as LUC), and also provide guidance to stakeholders and planners when selecting promising sites for algae cultivation.

\section{Methods}

In the national laboratory report (ANL et al., 2012) to harmonize environmental, economic, and resource assumptions surrounding algae production, the resource assessment team at Pacific Northwest National Laboratory conducted a nationwide review for algae facility locations that had favorable characteristics like sunlight, slope, freshwater availability, and proximity to other relevant supporting infrastructure for oil and fuel distribution. They identified 4,492 sites, across the Gulf Coast and Georgia, 
as the most promising areas. Among the data gathered by PNNL was the predominant current land use classification, and the potential facility locations were classified as either 'cropland', grassland', 'forestland', or 'marginal/barren' as a primary approximation for site characterization. Barren land has been defined by the IPCC as being land that is no longer being managed for useful purposes (IPCC, 2006b), but definitions of what constitutes marginal lands are often context-specific, as the term usually relates to the relative productivity of comparable lands.

In this study, the LUC impact on GHG emissions was analyzed across the range of potential locations that were deemed suitable for algae cultivation. Although each of the identified sites are large (485 ha) and likely contain several land use classes, sites were only classified according to primary land use classification. Figure 1 shows the potential locations of these sites, which are mostly located in the Gulf Coast area.

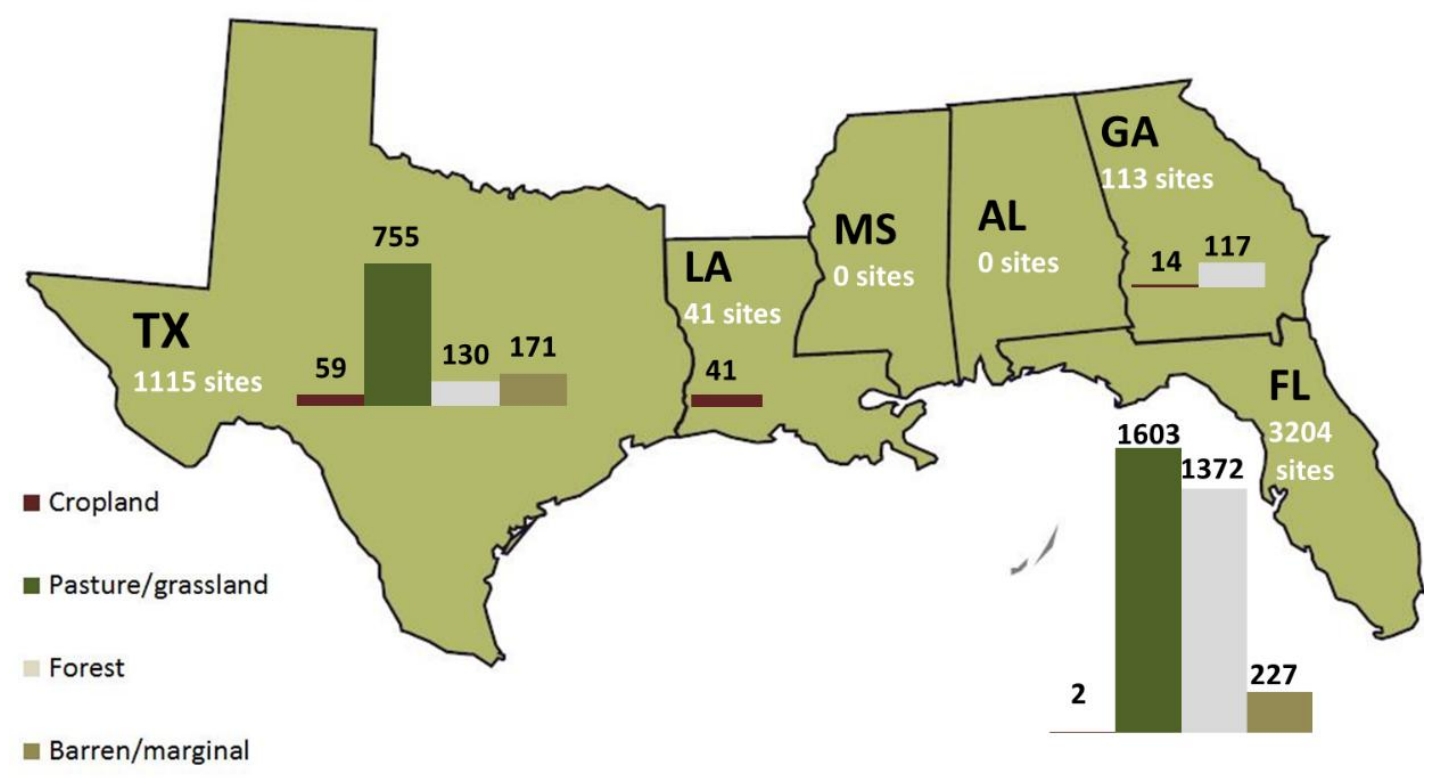

Figure 1. Previously identified potential sites for large-scale algae raceway facilities in the Southern United States. Sites identified by Pacific Northwest National Laboratory in support of ANL et al. (2012). 


\subsection{Goal and scope definition}

The goal of this study is to weigh the importance of land use change considerations in large-scale algae cultivation. The direct LUC emissions of algae feedstock cultivation will be summarized for conversions of grassland, cropland, and forestland, respectively. Scenarios will encompass particular combinations of location and prior land use type, in order to compare the potential LUC emissions resulting from different lands in different climate, regions, under different current management conditions. The functional unit for this analysis is defined as $1 \mathrm{MJ}$ of algae-based renewable diesel.

\subsection{Life cycle inventory analysis}

The IPCC has issued guidelines on the methods that should be used to evaluate national greenhouse gas inventories for a variety of sectors, including land use change. IPCC guidelines are published for different tiers of accuracy, based on the availability of national or regional-scale data or more in-depth modeling assessments of biomass and soil carbon changes (IPCC, 2006b). Tier 1 include simple methods with default values. Tier 2 are similar approaches but with country specific emission factors and other related data. Tier 3 are carried out with more sophisticate approaches and models, while compatible with the lower tiers. As an initial estimate, Tier 1 guidelines are used here, with the default IPCC values for biomass and soil carbon based upon different soil types, climate regions, and management practice of the areas in question.

IPCC Tier 1 guidance provides the estimates of soil organic carbon stocks based on $30 \mathrm{~cm}$ depth while limited data are available at Tier 2 for greater depth (IPCC, 2006c). Design of algae raceway ponds is critical to avoid the shadowing effect, where cells too deep in the water column are not sufficiently illuminated (Qiang et al., 1996). Therefore, it was assumed that the algae cultivation raceway ponds were 
built with a depth of about $0.3 \mathrm{~m}$, according to other authors from previous studies (Chisti, 2007; Parton et al., 1993). IPCC Tier 1 reference soil organic carbon $\left(\mathrm{SOC}_{\mathrm{ref}}\right)$ values for the first $30 \mathrm{~cm}$ of soil specified for relevant climate/soil combinations are included in Table 1.

Table 1. Average soil type, climate, and soil organic carbon assumptions for different regions.

\begin{tabular}{llll}
\hline U.S. Region & Soil Type $^{\mathrm{a}}$ & Cimate Zone $^{\mathrm{c}}$ & SOC $_{\text {ref }}$ (tonnes C / ha) \\
\hline South Florida 1 & LAC soils $^{\mathrm{d}}$ & tropical moist & 47 \\
\hline South Florida 2 & HAC soils & tropical moist & 65 \\
\hline North Florida & HAC soils & warm temperate moist & 88 \\
\hline Alabama - Mississippi & LAC soils & warm temperate moist & 63 \\
\hline Louisiana & Wetland soils, HAC soils & warm temperate moist & 88 \\
\hline East Texas & LAC soils & tropical dry & 35 \\
\hline South Texas & HAC soils & warm temperate dry & 38 \\
\hline Mid Texas & HAC soils & warm temperate dry & 38 \\
\hline New Mexico & HAC soils & warm temperate dry & 38 \\
\hline Arizona & HAC soils & warm temperate dry & 38 \\
\hline
\end{tabular}

a- based upon World Reference Base soil resources map (Stone, 1987) unless otherwise noted

b- based upon existing literature (Chen and Ma, 2001). HAC stands for high activity clay, LAC stands for low activity clay.

c- based upon IPCC climate zones- 2006 IPCC Guidelines for National Greenhouse Gas Inventories, Volume 4: Agriculture, Forestry and Other Land Use, Chapter 3 (IPCC, 2006d)

d- for 0-30 cm soil profile, according to IPPC Tier 1 default values - 2006 IPCC Guidelines for National Greenhouse Gas Inventories, Volume 4: Agriculture, Forestry and Other Land Use, Chapter 2 (IPCC, 2006c)

e- due to identical baseline values, Alabama and Mississippi are combined for the purposes of this analysis 
In the first set of LUC scenarios analyzed, we focus on three main changes:
A. Grasslands (varying condition) to settlements
B. Croplands (varying conditions) to settlements
C. Forestlands (varying conditions) to settlements

This study focused on conversion to 'settlements', described by the IPCC documents as a catch-all term for lands under large-scale development for residential, commercial, production, or transportation purposes. Conversion to algal cultivation raceway systems seems most analogous to permanently altering lands in such a way that inputs of organic matter from dead biomass are no longer feasible, akin to installing a parking lot or other impermeable infrastructure. The following sections will briefly highlight the important assumptions and IPCC reference data that were involved in calculating the LUC values for algal cultivation systems. Every LUC calculation involves consideration of living and dead biomass that may exist both above and belowground, in addition to organic matter present within the soil matrix. To ensure that LUC modeling captures every possible route of carbon stock change, it is important to include estimates of change for all of these biomass components.

\section{$\underline{\text { 2.2.1 Grassland systems }}$}

Grassland landscapes may have a range of current biomass stocks prior to conversion into another land use type. Land use conversion would presumably involve some type of site preparation activity that involves clearing the landscape of all or most existing biomass, along with changes to soil carbon stocks depending on new land management practices. Estimates of how much biomass carbon is lost upon conversion are varied according to IPCC Tier 1 estimates. This study focused on mechanical land clearing, since that activity would likely have to take place in order to level the site for raceways and install pond liners or other equipment. Estimates of biomass carbon lost from the landscape due to 
clearing of above and belowground biomass comes from Table 6.4 of the IPCC guidelines (IPCC, 2006e), assuming 0.47 tonnes $\mathrm{C}$ / tonne biomass, which is the IPCC default value (Table 2).

In order to model the changes to soil organic carbon, first it was necessary to define the many different types of grassland that could be converted. The IPCC Tier 1 guidelines take the initial SOC $_{\text {ref }}$ values based upon climate and soil type, and modify those values based upon the influence of land use, management, and soil input characteristics. For instance, a grassland in Alabama that was a long-term grassland $\left(\mathrm{F}_{\mathrm{LU}}=1.0\right)$ that was moderately degraded $\left(\mathrm{F}_{\mathrm{MG}}=0.95\right)$ with high external inputs $\left(\mathrm{F}_{\mathrm{I}}=1.11\right)$ would have a Tier 1 SOC value of:

$$
S O C_{\text {grass }}=S O C_{\text {ref }} * F_{L U} * F_{M G} * F_{I}=63 \frac{\text { tonnes } C}{h a} * 1.0 * 0.95 * 1.11=66.4 \frac{\text { tonnes } C}{h a}
$$

For each of the three soil types and four climate zones in the study, four basic grassland scenarios were defined below in Table 2, relying on IPCC Tier 1 values (IPCC, 2006e). These soil carbon values will be used to approximate the changes in soil carbon content upon conversion to settlements (algae raceways).

Table 2. Initial soil organic carbon values of different grassland scenarios used in case studies ${ }^{\mathrm{a}}$.

\begin{tabular}{lcccc}
\hline U.S. Region & $\begin{array}{c}\text { 1) Best-Case } \\
\text { (non-degraded, } \\
\text { high input) }\end{array}$ & $\begin{array}{c}\text { 2) Non-Degraded } \\
\text { (non-degraded, } \\
\text { moderate input) }\end{array}$ & $\begin{array}{c}\text { 3) Moderate } \\
\text { (mod. degradation } \\
\text { \& inputs) }\end{array}$ & $\begin{array}{c}\text { 3) Severe } \\
\text { (severe degradation, } \\
\text { moderate inputs) }\end{array}$ \\
\hline South Florida 1 & 52.2 & 47.0 & 45.6 & 32.9 \\
\hline South Florida 2 & 72.2 & 65.0 & 63.1 & 45.5 \\
\hline North Florida & 97.7 & 88.0 & 83.6 & 61.6 \\
\hline $\begin{array}{l}\text { Alabama- } \\
\text { Mississippi }\end{array}$ & 69.9 & 63.0 & 59.9 & 44.1 \\
\hline Louisiana & 97.7 & 88.0 & 83.6 & 61.6 \\
\hline East Texas & 38.9 & 35.0 & 34.0 & 24.5 \\
\hline South Texas & 42.2 & 38.0 & 36.1 & 26.6 \\
\hline Mid Texas & 42.2 & 38.0 & 36.1 & 26.6 \\
\hline
\end{tabular}


a - 2006 IPCC Guidelines for National Greenhouse Gas Inventories, Volume 4: Agriculture, Forestry and Other Land Use, Chapter 6 (IPCC, 2006e)

\subsubsection{Croplands}

The default assumption for aboveground biomass is that most of the biomass from the previous year's growing cycle would be removed prior to conversion of the cropland to algae raceways. The default low-range value for agricultural residues (1.9 tonnes $\mathrm{C} / \mathrm{ha}$ ) was applied to estimate these carbon losses in every climate / soil type (IPCC, 2006f). There is room for improvement of this estimate based upon specific knowledge of planned operations when conversion of cropland to algae raceways takes place, and this should be revisited as the industry begins to scale up. SOC values are calculated in an identical manner to the grassland example, using similar modification factors.

For each soil/climate zone in our study, three basic cropland scenarios were defined below in Table 3, relying on IPCC values (IPCC, 2006f). These soil carbon values will be used to approximate the changes in soil carbon content upon conversion to settlements (algae open pond raceways).

Table 3. Initial soil organic carbon values of different crop scenarios used in case studies ${ }^{\mathrm{a}}$.

\begin{tabular}{lccc}
\hline \multicolumn{4}{c}{$\mathrm{SOC}_{\text {init }}$ (tonnes C / ha) } \\
\hline U.S. Region & $\begin{array}{l}\text { 1) Set-aside / reserve } \\
\text { (set-aside, no tillage, } \\
\text { high inputs) }\end{array}$ & $\begin{array}{l}\text { 2) Moderately Degraded } \\
\text { (long-term cultivation, } \\
\text { reduced tillage, low inputs) }\end{array}$ & $\begin{array}{l}\text { 2) Severely Degraded } \\
\text { (long-term cultivation, } \\
\text { full tillage, low inputs) }\end{array}$ \\
\hline South Florida 1 & 52.2 & 23.9 & 20.8 \\
\hline South Florida 2 & 72.2 & 33.0 & 28.7 \\
\hline $\begin{array}{l}\text { Alabama- } \\
\text { Mississippi }\end{array}$ & 65.9 & 43.2 & 40.0 \\
\hline North Florida & 92.1 & 60.3 & 55.9 \\
\hline Louisiana & 92.1 & 60.3 & 55.9 \\
\hline East Texas & 39.6 & 21.0 & 19.3 \\
\hline South Texas & 40.4 & 29.5 & 28.9 \\
\hline Mid Texas & 40.4 & 29.5 & 28.9 \\
\hline
\end{tabular}


a - 2006 IPCC Guidelines for National Greenhouse Gas Inventories, Volume 4: Agriculture, Forestry and Other Land Use, Chapter 5 (IPCC, 2006g)

\section{$\underline{2.2 .3 \text { Forestlands }}$}

Study assumptions surrounding forestland conversion to settlements are somewhat different than other scenarios. IPCC Tier 1 guidance on soil carbon stocks in forestlands suggests that maintenance and management activities have an uncertain impact on soil carbon stocks, and the default values for each soil class/climate region should be used without modification. A similar conclusion has been reported in a large scale meta-analysis of forest harvesting practices and their impact on soil carbon stocks (Laha and Luthy, 1990). A comprehensive report that focuses on regional assessments of U.S. forest systems also supports this assertion (Smith et al., 2006). Forestlands contain above and belowground biomass stocks that are at least an order of magnitude higher than grasslands or croplands, according to IPCC guidance. IPCC data on forestland systems classifies the forest condition as tropical, subtropical, or temperate, with several sub-classifications within those groups. Based on the map contained within the IPCC report, each zone of interest was classified in the following manner (Table 4).

Table 4. Forest Classifications of different U.S states according to IPCC ${ }^{\text {. }}$

\begin{tabular}{ll}
\hline Region & Forest Classification \\
\hline Florida & Subtropical humid forest \\
\hline Alabama-Mississippi & Subtropical humid forest \\
\hline Louisiana & Subtropical humid forest \\
\hline East Texas & Subtropical steppe \\
\hline South Texas & Subtropical steppe \\
\hline Mid Texas & Subtropical steppe / subtropical desert (50/50 mix) \\
a - 2006 IPCC Guidelines for National Greenhouse Gas Inventories, Volume 4: Agriculture, Forestry \\
\multicolumn{2}{l}{ and Other Land Use, Chapter 4 (IPCC, 2006g) }
\end{tabular}


Estimates for forestland conversion to settlements include all above ground biomass (AGB) carbon and below ground biomass (BGB) carbon that is to be removed and lost to the atmosphere. The AGB (tonnes of dry matter / ha) for three main forest types (natural forest, conifer plantations, broadleaf plantations) in each forest condition was specified in the IPCC report, along with the ratio of belowground to aboveground biomass. This information was used along with a default parameter for carbon content in forest biomass ( 0.47 by weight, consistent with IPCC) to calculate the biomass stocks that would be cleared upon conversion of the forestlands (Table 5).

Table 5. Important parameters for forest biomass carbon calculations.

\begin{tabular}{lcccc}
\hline & \begin{tabular}{l} 
Ratio of \\
belowground: \\
aboveground \\
\cline { 3 - 5 } biomass
\end{tabular} & \multicolumn{3}{c}{$\begin{array}{c}\text { AGB+BGB Carbon } \\
\text { tonnes C / ha }\end{array}$} \\
\cline { 3 - 5 } Forest condition & 0.2 & 124.1 & 152.3 & 56.4 \\
\hline Subtropical humid forest & Natural forests & $\begin{array}{c}\text { Conifer } \\
\text { plantations }\end{array}$ & $\begin{array}{c}\text { Broadleaf } \\
\text { plantations }\end{array}$ \\
\hline Subtropical dry forest $^{\mathrm{a}}$ & 0.28 & 154.0 & 80.7 & 44.0 \\
\hline Subtropical steppe $^{\mathrm{a}}$ & 0.32 & 49.6 & 37.2 & 18.6 \\
\hline subtropical desert $^{\mathrm{b}}$ & 0.1 & 4.1 & 4.1 & 4.1 \\
\hline
\end{tabular}

a - 2006 IPCC Guidelines for National Greenhouse Gas Inventories, Volume 4: Agriculture, Forestry and Other Land Use, Chapter 4 (IPCC, 2006g)

b - Factors for subtropical desert have been assumed to be similar to desert grasslands (U.S. EPA, 2016). 
The fate of forestland biomass carbon after clearing is certainly a matter that is open for debate, and due to the large amount of biomass carbon present on forested landscapes, management decisions surrounding this carbon pool may have important impacts on the GHG emissions from LUC. In the worst case, cleared biomass would be piled and burned, emitting basically all of the carbon to the atmosphere as $\mathrm{CO}_{2}$. On the other end, a valuable, long-lived product stream such as furniture or lumber could be produced from the cleared biomass. In addition to storing a large fraction of the carbon for a long time frame, this creation of a valuable product from this stage of the algae production process would mean that environmental burdens from this stage should be allocated between the algae products and these algae infrastructure development by-products, further reducing the LUC emissions penalty attributed to algae fuels. Here, it is assumed that the forestland that would be targeted for clearing and conversion to largescale algae raceways contains lower-value wood that is not being developed over the long term for high value sawlogs, and contains wood that would normally have no target market save for pulp and paper or wood chip production for energy markets (Langholz et al., 2015; Aguilar and Garrett, 2009). It is therefore assumed that minimal long-term storage of carbon is achieved in these pulp and paper or energy by-products (e.g. Skog and Nicholson, 1998), and that $90 \%$ of the biomass forest carbon is emitted as $\mathrm{CO}_{2}$ over the life of the algae facility.

\subsubsection{Conversion of all lands to settlements}

The default guidance for IPCC Tier 1 estimates for conversion to settlements is that all above and belowground biomass carbon is assumed to be lost to the atmosphere. Furthermore, the soil organic carbon in the first $30 \mathrm{~cm}$ of soil is assumed to be reduced by $20 \%$ (IPCC, 2006c). For the portion of settlement area that is retained as turfgrass (similar to a maintained residential lawn), the soil organic carbon values should be comparable to an improved grassland from the IPCC definition, because it would receive periodic management such as fertilization, species management, or irrigation. The turfgrass 
assumption in our algae cultivation scenarios is $8 \%$ of the total facility area, which amounts to half of the area of the unit operations facilities footprint modeled in ANL et al. (2012), but not directly covered by algae ponds. Changes in SOC are assumed to take place over a period of 20 years, with constant annual incremental changes taking place to achieve the required reduction. For the sake of consistency, biomass carbon stock changes were also assumed to occur over the same 20 -year period, in order to average out the impacts of biomass carbon loss to the atmosphere over the lifetime of fuel production at a facility. In practice, the majority of this loss will likely take place in Year 0 or Year 1 of operations due to initial land clearing and more rapid initial biomass decay or active incineration of cleared biomass. Allocating these early-stage changes to the entire pool of fuel products created from these facilities follows the methodological approach outlined by the IPCC for carbon stock changes (IPCC, 2006c), and would avoid the complication of creating different environmental profiles for different age-classes of fuel products.

\section{$\underline{2.2 .5 \text { Scale of algae cultivation system }}$}

The previously-discussed harmonization study authored by national laboratory agencies (ANL et al., 2012) will serve as guidance for the magnitude of land use change caused by these algae facilities. The report suggests that to achieve annual production of 5 billion gallons of renewable diesel fuel, 446 algaeproducing facilities are needed, each facility consisting of 10 sites of 485 ha (4,460 sites total). Of these 485 ha, roughly $84 \%$ of the land area is devoted to raceway ponds (ANL et al., 2012; Wigmosta et al., 2011), while the rest is assumed to be required for other processing facilities, walkways, and general infrastructure.

Considering all of the potential land use change possibilities outlined in Sections 2.2.1-2.2.3, 80 total scenarios were considered. For each scenario, carbon losses per hectare of developed land was calculated. If it is assumed that all 4,460 algae production facilities are situated in the same climate/soil region and will undergo the same extent of land use change, multiplying the per hectare carbon loss with the total required hectares to achieve 5 billion gallons of annual fuel production gives the total carbon loss for that 
specific land use conversion scenario. These carbon losses are converted to $\mathrm{CO}_{2}$ emissions, and the mass of $\mathrm{CO}_{2}$ is normalized by the total $\mathrm{MJ}$ of fuel production (assuming an energy content of $43 \mathrm{MJ} / \mathrm{kg}$ and a density of $0.832 \mathrm{~kg} / \mathrm{L}$ for diesel fuel (ANL, 2014)) to result in GHG emissions due to LUC in units of $\mathrm{g}$ $\mathrm{CO}_{2} / \mathrm{MJ}$ fuel. To account for the portions of the algae cultivation facility area that are not converted to algae raceways, it is assumed that half of the non-raceway land area within the algae facilities ( 8\% of required area) is retained as turfgrass.

\subsubsection{Alternative scenario}

Creation of low-value by-products from forest biomass during the construction process of algae raceway ponds could mean environmental burdens from this stage should be allocated between the algae products (fuel, chemicals) and these infrastructure development by-products, further reducing the LUC emissions penalty attributed to algae fuels. One factor considered in an alternative scenario when evaluating LUC implications for algae raceways was the potential benefit of utilizing cleared biomass for wood chip production and power generation, and how that by-product use would impact life cycle emissions of algae-based fuels. Energy allocation was used to distribute GHG emissions from forest biomass clearing between renewable diesel and electricity products. On a forested site in the most common climate zone for this study (humid regions), average aboveground biomass is 220 tonnes /ha (IPCC, 2006g). Using parameters from the GREET model for the lower heating value of forest biomass (15,400 MJ / tonne) and electricity generation efficiency (19.4\%) (Argonne National Laboratory, 2014), we can estimate the total MJ of electricity generation from one forested site is $3.18 \times 10^{8}$ MJ. While this represents a sizeable electricity production, it is small relative to the 20 -year lifetime production of renewable diesel from that same 485 ha site. Using the stated 5 billion gallon per year target diesel production across all 4,460 sites, it is possible to estimate an average production rate per site, which 
would result in a lifetime production of $3.03 \times 10^{9} \mathrm{MJ}$ per site, assuming a lower heating value of $43 \mathrm{MJ} /$ $\mathrm{kg}$ and a density of $0.832 \mathrm{~kg} / \mathrm{L}$ for diesel fuel).

\section{Results and discussion}

This analysis of IPCC Tier 1 LUC impacts on GHG emissions across the range of potential locations deemed suitable for algae cultivation resulted in several scenarios based on specific combinations of location and prior land use type. Tables 6, 7, and 8 below summarize LUC emissions for conversions of grassland, cropland, and forestland, respectively. Grassland scenarios investigated range from 3.5 (converting severely degraded grasslands in dry areas) to over $13 \mathrm{~g} \mathrm{CO}_{2 \mathrm{eq}} / \mathrm{MJ} \mathrm{RD}$ when converting healthy grasslands in lush ecosystems. In every grassland scenario evaluated, a majority of the carbon lost in the system would come from soil carbon. Similarly, cropland ecosystems were estimated to emit between 1.7 and $10.1 \mathrm{~g} \mathrm{CO}_{2 \mathrm{eq}} / \mathrm{MJ}$ fuel due to direct LUC, with a majority of carbon loss coming from soil carbon disturbances as opposed to biomass removals.

Average forestland LUC GHG emissions would carry a much larger penalty $\left(42.5 \mathrm{~g} \mathrm{CO}_{2 \mathrm{eq}} / \mathrm{MJ}\right)$ than either cropland or grassland (4.7 and $7.9 \mathrm{~g} \mathrm{CO}_{2 \mathrm{eq}} / \mathrm{MJ}$, respectively). As discussed previously, this is due to the large amount of biomass carbon that needs to be removed if forests are to be cleared for algal raceway construction - biomass removals are an order of magnitude higher across the range of forestland scenarios than grassland scenarios, while soil carbon loss is roughly equivalent. The study assumption common to all scenarios that a small portion $(\sim 8 \%)$ of the algal cultivation facility is retained as turfgrass results in a lowering of GHG emissions from LUC by roughly $1.3-1.8 \mathrm{~g} \mathrm{CO}_{2} / \mathrm{MJ}$, depending on the prior state and management condition of the lands being converted to turfgrass. 
Table 6. Grassland Scenarios for algae cultivation land use change.

\begin{tabular}{|c|c|c|c|c|c|}
\hline \multirow{2}{*}{\multicolumn{2}{|c|}{ Grassland Scenarios }} & \multicolumn{2}{|c|}{$\begin{array}{l}\text { Carbon Lost } \\
\text { (tonnes C / ha) }\end{array}$} & \multirow{2}{*}{$\begin{array}{c}\mathrm{CO}_{2} \text { emissions } \\
\text { (tonnes } \mathrm{CO}_{2} / \\
\text { ha) } \\
\text { 20-year average }\end{array}$} & \multirow{2}{*}{$\begin{array}{c}\mathrm{LUC} \mathrm{CO}_{2} \\
\text { emissions } \\
\left(\mathrm{g} \mathrm{CO}_{2} / \mathrm{MJ}\right)\end{array}$} \\
\hline & & \multirow[t]{2}{*}{ Biomass } & \multirow[t]{2}{*}{ Soil Carbon } & & \\
\hline Location & Condition & & & & \\
\hline \multirow{4}{*}{$\begin{array}{l}\text { South } \\
\text { Florida } 1\end{array}$} & best & 7.6 & 10.4 & 3.3 & 9.2 \\
\hline & non-degraded & 7.6 & 9.4 & 3.1 & 8.4 \\
\hline & mod. degraded & 7.6 & 9.1 & 3.1 & 8.2 \\
\hline & severely degraded & 7.6 & 6.6 & 2.6 & 6.4 \\
\hline \multirow{4}{*}{$\begin{array}{l}\text { South } \\
\text { Florida } 2\end{array}$} & best & 7.6 & 14.4 & 4.0 & 11.2 \\
\hline & non-degraded & 7.6 & 13.0 & 3.8 & 10.2 \\
\hline & mod. degraded & 7.6 & 12.6 & 3.7 & 9.9 \\
\hline & severely degraded & 7.6 & 9.1 & 3.1 & 7.3 \\
\hline \multirow{4}{*}{$\begin{array}{l}\text { Alabama - } \\
\text { Mississippi }\end{array}$} & best & 6.3 & 14.0 & 3.7 & 10.4 \\
\hline & non-degraded & 6.3 & 12.6 & 3.5 & 9.3 \\
\hline & Mod. degraded & 6.3 & 12.0 & 3.4 & 8.9 \\
\hline & severely degraded & 6.3 & 8.8 & 2.8 & 6.6 \\
\hline \multirow{4}{*}{$\begin{array}{l}\text { North } \\
\text { Florida }\end{array}$} & best & 6.3 & 19.5 & 4.7 & 13.2 \\
\hline & non-degraded & 6.3 & 17.6 & 4.4 & 11.8 \\
\hline & mod. degraded & 6.3 & 16.7 & 4.2 & 11.1 \\
\hline & severely degraded & 6.3 & 12.3 & 3.4 & 7.9 \\
\hline \multirow[t]{4}{*}{ Louisiana } & best & 6.3 & 19.5 & 4.7 & 13.2 \\
\hline & non-degraded & 6.3 & 17.6 & 4.4 & 11.8 \\
\hline & mod. degraded & 6.3 & 16.7 & 4.2 & 11.1 \\
\hline & severely degraded & 6.3 & 12.3 & 3.4 & 7.9 \\
\hline \multirow[t]{4}{*}{ East Texas } & best & 4.1 & 7.8 & 2.2 & 6.0 \\
\hline & non-degraded & 4.1 & 7.0 & 2.0 & 5.5 \\
\hline & mod. degraded & 4.1 & 6.8 & 2.0 & 5.3 \\
\hline & severely degraded & 4.1 & 4.9 & 1.6 & 3.9 \\
\hline \multirow[t]{4}{*}{ South Texas } & best & 2.9 & 8.4 & 2.1 & 5.8 \\
\hline & non-degraded & 2.9 & 7.6 & 1.9 & 5.1 \\
\hline & mod. degraded & 2.9 & 7.2 & 1.8 & 4.9 \\
\hline & severely degraded & 2.9 & 5.3 & 1.5 & 3.5 \\
\hline \multirow[t]{4}{*}{ Mid Texas } & best & 2.9 & 8.4 & 2.1 & 5.8 \\
\hline & non-degraded & 2.9 & 7.6 & 1.9 & 5.1 \\
\hline & mod. degraded & 2.9 & 7.2 & 1.8 & 4.9 \\
\hline & severely degraded & 2.9 & 5.3 & 1.5 & 3.5 \\
\hline Averages & & 5.5 & 10.9 & 3.0 & 7.9 \\
\hline
\end{tabular}


Table 7. Cropland scenarios for algae cultivation land use change.

\begin{tabular}{|c|c|c|c|c|c|}
\hline & & \multicolumn{2}{|c|}{$\begin{array}{l}\text { Carbon Lost } \\
\text { (tonnes C / ha) }\end{array}$} & \multirow{2}{*}{$\begin{array}{c}\mathrm{CO}_{2} \text { emissions } \\
\text { (tonnes } \mathrm{CO}_{2} / \\
\text { ha) }\end{array}$} & \multirow{2}{*}{$\begin{array}{c}\mathrm{LUC} \mathrm{CO}_{2} \\
\text { emissions } \\
\left(\mathrm{g} \mathrm{CO}_{2} / \mathrm{MJ}\right) \\
\end{array}$} \\
\hline \multicolumn{2}{|c|}{ Cropland Scenarios } & Biomass & $\begin{array}{c}\text { Soil } \\
\text { Carbon }\end{array}$ & & \\
\hline Location & Condition & & & & \\
\hline \multirow[t]{3}{*}{ South Florida 1} & set-aside CRP & 1.9 & 10.4 & 2.3 & 6.3 \\
\hline & mod. degraded & 1.9 & 4.8 & 1.2 & 2.1 \\
\hline & $\begin{array}{l}\text { severely } \\
\text { degraded }\end{array}$ & 1.9 & 4.2 & 1.1 & 1.7 \\
\hline \multirow[t]{3}{*}{ South Florida 2} & set-aside CRP & 1.9 & 14.4 & 3.0 & 8.3 \\
\hline & mod. degraded & 1.9 & 6.6 & 1.6 & 2.6 \\
\hline & $\begin{array}{l}\text { severely } \\
\text { degraded }\end{array}$ & 1.9 & 5.7 & 1.4 & 2.0 \\
\hline \multirow{3}{*}{$\begin{array}{l}\text { Alabama- } \\
\text { Mississippi }\end{array}$} & set-aside CRP & 1.9 & 13.2 & 2.8 & 7.5 \\
\hline & mod. degraded & 1.9 & 8.6 & 1.9 & 4.2 \\
\hline & $\begin{array}{l}\text { severely } \\
\text { degraded }\end{array}$ & 1.9 & 8.0 & 1.8 & 3.7 \\
\hline \multirow[t]{3}{*}{ North Florida } & set-aside CRP & 1.9 & 18.4 & 3.7 & 10.1 \\
\hline & mod. degraded & 1.9 & 12.1 & 2.6 & 5.4 \\
\hline & $\begin{array}{l}\text { severely } \\
\text { degraded }\end{array}$ & 1.9 & 11.2 & 2.4 & 4.8 \\
\hline \multirow[t]{3}{*}{ Louisiana } & set-aside CRP & 1.9 & 18.4 & 3.7 & 10.1 \\
\hline & mod. degraded & 1.9 & 12.1 & 2.6 & 5.4 \\
\hline & $\begin{array}{l}\text { severely } \\
\text { degraded }\end{array}$ & 1.9 & 11.2 & 2.4 & 4.8 \\
\hline \multirow[t]{3}{*}{ East Texas } & set-aside CRP & 1.9 & 7.9 & 1.8 & 5.0 \\
\hline & mod. degraded & 1.9 & 4.2 & 1.1 & 2.3 \\
\hline & $\begin{array}{l}\text { severely } \\
\text { degraded }\end{array}$ & 1.9 & 3.9 & 1.1 & 2.1 \\
\hline \multirow[t]{3}{*}{ South Texas } & set-aside CRP & 1.9 & 8.1 & 1.8 & 5.0 \\
\hline & mod. degraded & 1.9 & 5.9 & 1.4 & 3.4 \\
\hline & $\begin{array}{l}\text { severely } \\
\text { degraded }\end{array}$ & 1.9 & 5.8 & 1.4 & 3.3 \\
\hline \multirow[t]{3}{*}{ Mid Texas } & set-aside CRP & 1.9 & 8.1 & 1.8 & 5.0 \\
\hline & mod. degraded & 1.9 & 5.9 & 1.4 & 3.4 \\
\hline & $\begin{array}{l}\text { severely } \\
\text { degraded }\end{array}$ & 1.9 & 5.8 & 1.4 & 3.3 \\
\hline Averages & & 1.9 & 8.9 & 2.0 & 4.7 \\
\hline
\end{tabular}


Table 8. Forestland Scenarios for Algae cultivation land use change.

\begin{tabular}{|c|c|c|c|c|c|}
\hline & & \multicolumn{2}{|c|}{$\begin{array}{l}\text { Carbon Lost } \\
\text { (tonnes C / ha) }\end{array}$} & \multirow{2}{*}{$\begin{array}{c}\mathrm{CO}_{2} \text { emissions } \\
\text { (tonnes } \mathrm{CO}_{2} / \mathrm{ha} \text { ) } \\
\begin{array}{c}20 \text {-year } \\
\text { average }\end{array} \\
\end{array}$} & \multirow{2}{*}{$\begin{array}{c}\mathrm{LUC} \mathrm{CO}_{2} \\
\text { emissions } \\
\left(\mathrm{g} \mathrm{CO}_{2} / \mathrm{MJ}\right)\end{array}$} \\
\hline \multicolumn{2}{|c|}{ Cropland Scenarios } & Biomass & $\begin{array}{c}\text { Soil } \\
\text { Carbon }\end{array}$ & & \\
\hline Location & Condition & & & & \\
\hline \multirow[t]{3}{*}{ South Florida 1} & natural forest & 111.7 & 9.4 & 22.2 & 61.4 \\
\hline & pine plantation & 137.1 & 9.4 & 26.8 & 74.3 \\
\hline & $\begin{array}{l}\text { broadleaf } \\
\text { plantation }\end{array}$ & 50.8 & 9.4 & 11.0 & 30.4 \\
\hline \multirow[t]{3}{*}{ South Florida 2} & natural forest & 111.7 & 13 & 22.9 & 63.2 \\
\hline & pine plantation & 137.1 & 13 & 27.5 & 76.1 \\
\hline & $\begin{array}{l}\text { broadleaf } \\
\text { plantation }\end{array}$ & 50.8 & 13 & 11.7 & 32.2 \\
\hline \multirow{3}{*}{$\begin{array}{l}\text { Alabama- } \\
\text { Mississippi }\end{array}$} & natural forest & 111.7 & 12.6 & 22.8 & 63.0 \\
\hline & pine plantation & 137.1 & 12.6 & 27.4 & 75.9 \\
\hline & $\begin{array}{l}\text { broadleaf } \\
\text { plantation }\end{array}$ & 50.8 & 12.6 & 11.6 & 32.0 \\
\hline \multirow[t]{3}{*}{ North Florida } & natural forest & 111.7 & 17.6 & 23.7 & 65.4 \\
\hline & pine plantation & 137.1 & 17.6 & 28.4 & 78.3 \\
\hline & $\begin{array}{l}\text { broadleaf } \\
\text { plantation }\end{array}$ & 50.8 & 17.6 & 12.5 & 34.4 \\
\hline \multirow[t]{3}{*}{ Louisiana } & natural forest & 111.7 & 17.6 & 23.7 & 65.4 \\
\hline & pine plantation & 137.1 & 17.6 & 28.4 & 78.3 \\
\hline & $\begin{array}{l}\text { broadleaf } \\
\text { plantation }\end{array}$ & 50.8 & 17.6 & 12.5 & 34.4 \\
\hline \multirow[t]{3}{*}{ East Texas } & natural forest & 44.7 & 7.0 & 9.5 & 26.1 \\
\hline & pine plantation & 33.5 & 7.0 & 7.4 & 20.5 \\
\hline & $\begin{array}{l}\text { broadleaf } \\
\text { plantation }\end{array}$ & 16.8 & 7.0 & 4.4 & 11.9 \\
\hline \multirow[t]{3}{*}{ South Texas } & natural forest & 44.7 & 7.6 & 9.6 & 26.4 \\
\hline & pine plantation & 33.5 & 7.6 & 7.5 & 20.7 \\
\hline & $\begin{array}{l}\text { broadleaf } \\
\text { plantation }\end{array}$ & 16.8 & 7.6 & 4.5 & 12.2 \\
\hline \multirow[t]{3}{*}{ Mid Texas } & natural forest & 24.2 & 7.6 & 5.8 & 16.0 \\
\hline & pine plantation & 18.6 & 7.6 & 4.8 & 13.2 \\
\hline & $\begin{array}{l}\text { broadleaf } \\
\text { plantation }\end{array}$ & 10.2 & 7.6 & 3.3 & 8.9 \\
\hline Averages & & 72.5 & 11.6 & 15.4 & 42.5 \\
\hline
\end{tabular}




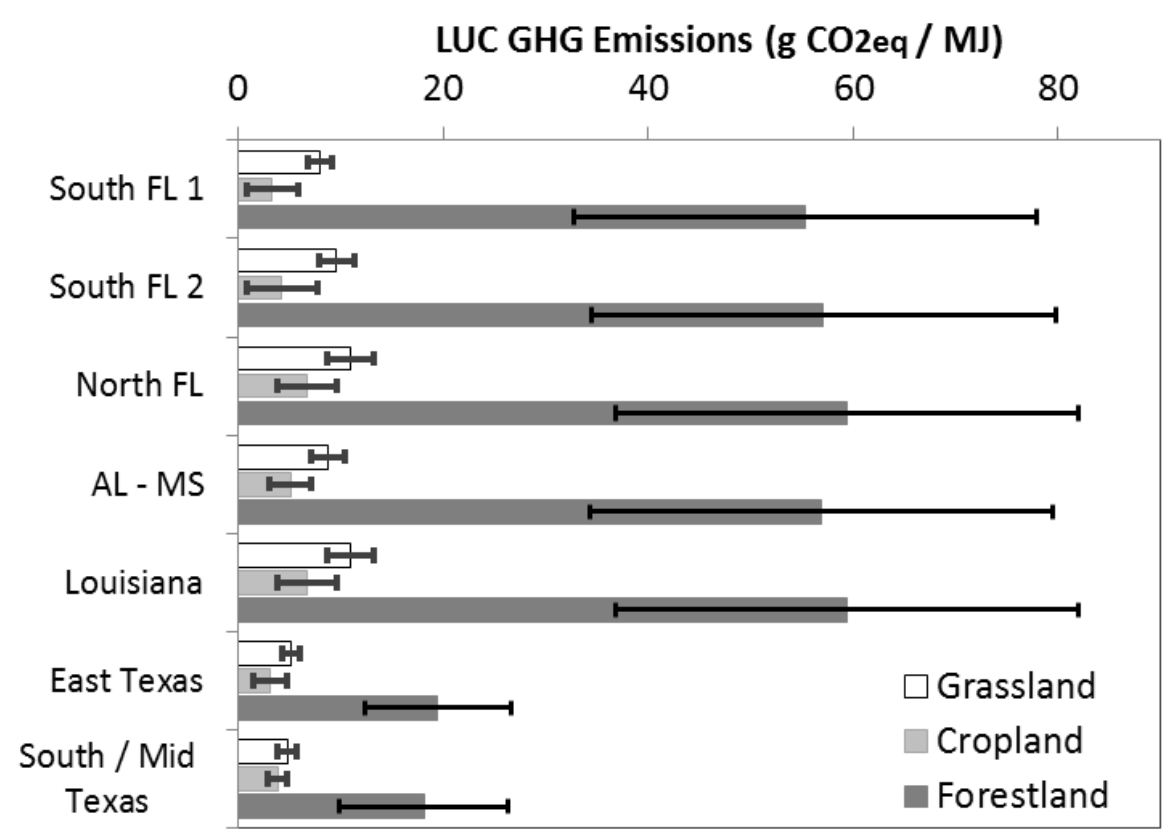

Figure 2. Averages of LUC emissions by region and primary land cover type. Error bars represent standard deviations of all averaged scenarios from tables above.

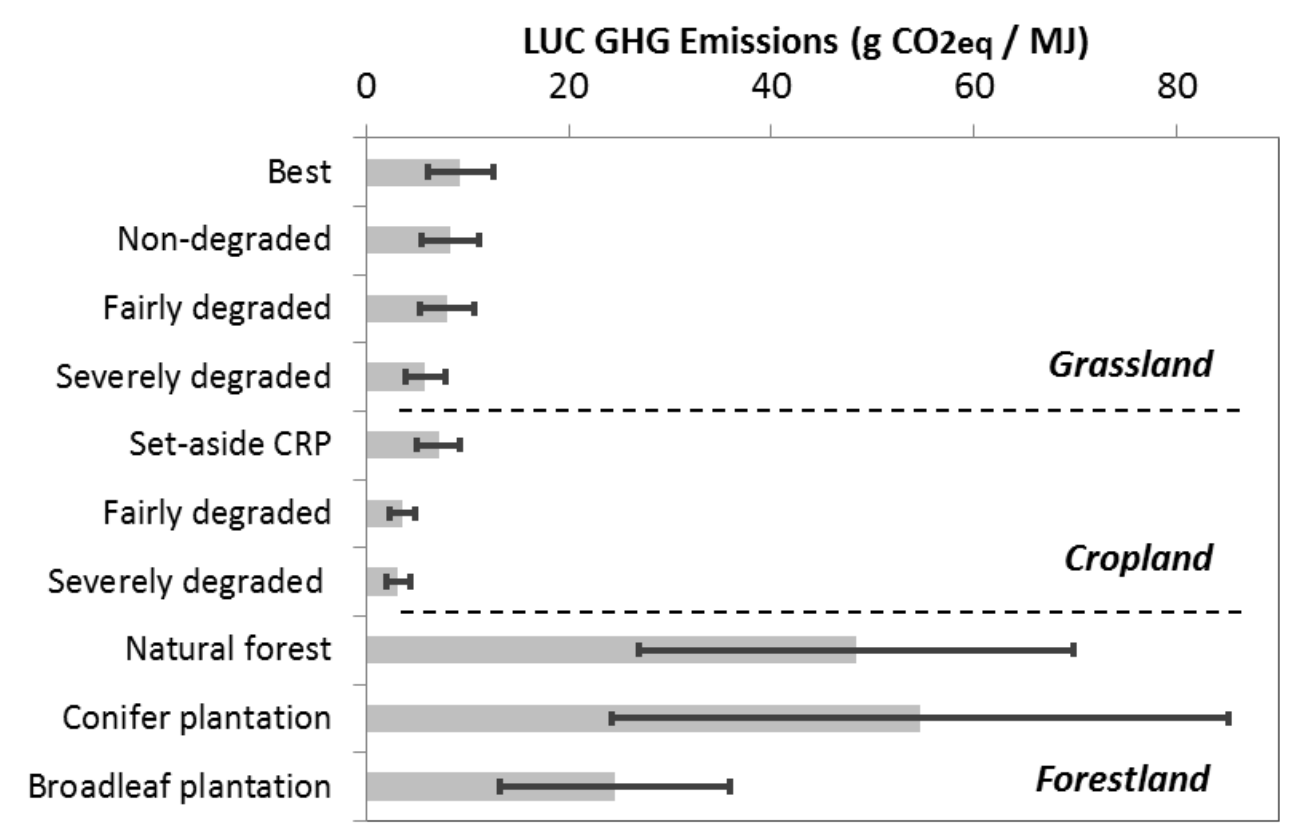

Figure 3. Averages of LUC emissions by land cover sub-classification. Error bars represent standard deviations of all averaged scenarios from tables above. 
If the variability of data within the three main land classifications is examined in Figures 2 and 3 , it is apparent that depending on the condition of the prior land use, or the region of the country, results can vary widely. In general, LUC emissions for the humid regions of the Gulf Coast appear to be larger than the arid regions of Texas. For each condition assessed in Figures 2 and 3 , the standard deviation of calculated results is quite large, reflecting the need to collect preconversion land information on each parcel of land under consideration for conversion to algae facilities.

Using site location information from ANL et al. (2012), it is possible to estimate potential LUC impacts for all sites under consideration (Table 9), using the locations of potential sites and the IPCC estimates relevant to land characteristics and management types for those sites created above in Tables 6-8. Site classifications in each region are combined with the LUC data above to present the weighted average of direct LUC for the entire set of potential algae cultivation sites. The resulting weighted average across all algae cultivation sites of interest in ANL et al. (2012) is to $24.7 \mathrm{~g} \mathrm{CO}_{2 \text { eq }}$ per $\mathrm{MJ}$ of renewable diesel (RD). This is quite important when compared to the average life cycle GHG emissions assumed in ANL et al. (2012) for the entire algae life cycle, without considering LUC (63.9 $\mathrm{g} \mathrm{CO}_{2 \mathrm{eq}} / \mathrm{MJ} \mathrm{RD}$ ), representing a 39\% increase in the baseline GHG emissions profile of RD. 
Table 9. Weighted average of potential LUC impacts for algae cultivation in the U.S. Gulf Coast.

\begin{tabular}{|c|c|c|c|}
\hline State / site classification & No. of sites & $\%$ of State (or total) & $\begin{array}{l}\text { Weighted LUC } \\
\text { GHG Emissions } \\
\left(\mathrm{g} \mathrm{CO}_{2 \mathrm{eq}} / \mathrm{MJ} \mathrm{RD}\right)\end{array}$ \\
\hline Texas & 1115 & 24.8 & 6.4 \\
\hline Cropland & 59 & 5.3 & 4.0 \\
\hline Pasture/grassland & 755 & 67.7 & 5.4 \\
\hline Forestland & 130 & 11.7 & 17.4 \\
\hline Barren/marginal & 171 & 15.3 & 3.3 \\
\hline Louisiana & 41 & 0.9 & 12.0 \\
\hline Pasture/grassland & 41 & 100.0 & 12.0 \\
\hline $\mathrm{AL} / \mathrm{MS}$ & 0 & 0.0 & 0 \\
\hline Georgia & 131 & 2.9 & 51.9 \\
\hline Pasture/grassland & 14 & 10.7 & 9.5 \\
\hline Forest & 117 & 89.3 & 56.9 \\
\hline Florida & 3204 & 71.3 & 30.1 \\
\hline Cropland & 2 & 0.1 & 5.8 \\
\hline Pasture/grassland & 1603 & 50.0 & 10.3 \\
\hline Forest & 1372 & 42.8 & 57.3 \\
\hline Barren/marginal & 227 & 7.1 & 5.0 \\
\hline Total & 4492 & & 24.7 \\
\hline
\end{tabular}

An alternative scenario in this study examined the by-product forest biomass from clearing forested lands for algae raceways for power generation by co-firing in an electricity generation facility. Comparing the $\mathrm{MJ}$ of electricity that could be generated from forest biomass on a given site $\left(3.18 \times 10^{8} \mathrm{MJ}\right.$ electricity) to the 20-year lifetime production of renewable diesel from that same site (3.03 x $\left.10^{9} \mathrm{MJ} \mathrm{RD}\right)$, the energy content of RD exceeds the energy content of electricity by almost a full order of magnitude. If we use an energy allocation approach to allocate environmental impacts between these two products, it then follows that roughly $90 \%\left(=3.03 \times 10^{9} \mathrm{MJ} /\left(3.03 \times 10^{9} \mathrm{MJ}+3.18 \times 10^{8}\right)\right)$ of the environmental impacts should be allocated to the biofuel product in forestland sites. If the forestland emission factors in Table 9 above were multiplied by this energy allocation factor of 0.9 to account for the fact that only $90 \%$ 
of forestland emissions would be attributable to the renewable diesel, the resulting system-wide average LUC emissions for the entire system would shrink from 24.7 to $22.8 \mathrm{~g} \mathrm{CO}_{2 \mathrm{eq}} / \mathrm{MJ} \mathrm{RD}$. From this analysis, it appears that assuming a favorable scenario of bioelectricity production from the large amounts of aboveground biomass generated from forestland clearing would not meaningfully alter the overall LUC emissions result of this study. This is due to the fact that sites would produce much more energy in renewable diesel over the project lifetime than they would produce in a one-time clearing of forest biomass, which is encouraging news for algae cultivators, but does not help to alleviate the considerable burden of LUC emissions from the life cycle of algae-based fuels.

Tables 10 and 11 offer comparisons to related LCA studies, to place the results of this study in context with other relevant work. Several dozen LCA studies have been published in recent years, with many different system boundaries, operating assumptions, and sources of input data, making it hard to directly compare a set of studies without detailed investigation, but a subset of recent studies with similar functional units and system boundaries are displayed alongside this study in Table 10. In general, most of the scenarios in these studies predict algae biofuels life cycle GHG emissions between $\sim 25-70 \mathrm{~g} \mathrm{CO}_{2 \mathrm{eq}} /$ MJ fuel, but none of these prior studies include the impacts of land use change in regards to cultivation, which we have shown in this study to be potentially on the same order of magnitude as these results which characterize all other aspects of the algae life cycle. Additionally, in Table 11, a set of recent studies that summarize land use change GHG emissions impacts for a set of other common biofuel pathways is presented alongside the base case result for our study. Land use change impacts can vary widely for a given fuel pathway, depending on the input data sets and assumptions about the effects of crop expansion on soil carbon and other market responses, but we can see in Table 11 that LUC emissions impacts predicted for large scale algae biofuels development in this study could be on the same order of magnitude as the LUC impacts estimated for other biofuel crops. The scenarios evaluated by Fritsche et al. (2010) specifically highlight the negative implications of converting a higher portion of forestland to cultivated land, as opposed to grassland, which is a common feature present in this work as well. 
Table 10. Comparison of other algae LCA studies with the current study

\begin{tabular}{|c|c|c|c|c|c|}
\hline Reference & $\begin{array}{l}\text { Cultivation } \\
\text { System }\end{array}$ & $\begin{array}{l}\text { Nutrient } \\
\text { source }\end{array}$ & $\begin{array}{l}\text { Harvest, } \\
\text { Dewatering, } \\
\text { Extraction } \\
\text { Systems }\end{array}$ & $\begin{array}{l}\text { Fuel Conversion } \\
\text { System }\end{array}$ & $\begin{array}{l}\text { LCA results } \\
\mathrm{GHG} \text { emissions } \\
\left(\mathrm{g} \mathrm{CO}_{2 \mathrm{eq}} / \mathrm{MJ}\right. \\
\text { fuel) }\end{array}$ \\
\hline $\begin{array}{l}\text { Woertz et } \\
\text { al. } 2014\end{array}$ & Open pond & Wastewater & $\begin{array}{l}\text { Bioflocculation, } \\
\text { Settling, } \\
\text { Solar drying, } \\
\text { Hexane }\end{array}$ & Transesterification & 28.5 \\
\hline $\begin{array}{l}\text { Quinn et al. } \\
2014\end{array}$ & Open pond & Variable & $\begin{array}{l}\text { Dissolved air } \\
\text { flotation, } \\
\text { Centrifuge, } \\
\text { Hexane }\end{array}$ & Transesterification & $25.5-71.7$ \\
\hline $\begin{array}{l}\text { Orfield et } \\
\text { al. } 2015\end{array}$ & $\begin{array}{l}\text { Open pond vs. } \\
\text { Heterotrophic } \\
\text { photobioreactor }\end{array}$ & $\begin{array}{l}\text { Chemical } \\
\text { fertilizers }\end{array}$ & $\begin{array}{l}\text { Dissolved air } \\
\text { flotation, } \\
\text { Centrifuge, } \\
\text { Hexane }\end{array}$ & Transesterification & $53-119$ \\
\hline $\begin{array}{l}\text { Stephenson } \\
\text { et al. } 2010\end{array}$ & $\begin{array}{l}\text { Open pond vs. } \\
\text { Tubular } \\
\text { photobioreactor }\end{array}$ & $\begin{array}{l}\text { Chemical } \\
\text { fertilizers }\end{array}$ & $\begin{array}{l}\text { Flocculation, } \\
\text { Centrifuge }\end{array}$ & Transesterification & $19-318$ \\
\hline $\begin{array}{l}\text { Bennion et } \\
\text { al. } 2015\end{array}$ & Open pond & $\begin{array}{l}\text { Chemical } \\
\text { fertilizers }\end{array}$ & $\begin{array}{l}\text { Membrane, } \\
\text { Centrifuge }\end{array}$ & HTL vs. Pyrolysis & $62.7-240$ \\
\hline $\begin{array}{l}\text { Passell et al. } \\
2013\end{array}$ & Open pond & $\begin{array}{l}\text { Chemical } \\
\text { fertilizers }\end{array}$ & $\begin{array}{l}\text { Flocculation, } \\
\text { Centrifuge, } \\
\text { Hexane }\end{array}$ & Transesterification & 180 \\
\hline $\begin{array}{l}\text { ANL et al. } \\
2012+ \\
\text { This Study }\end{array}$ & Open pond & $\begin{array}{l}\text { Chemical } \\
\text { fertilizers }\end{array}$ & $\begin{array}{l}\text { Dissolved air } \\
\text { flotation, } \\
\text { Centrifuge, } \\
\text { Hexane }\end{array}$ & Hydrotreating & $\begin{array}{l}63.9(\mathrm{ANL})+24.7 \\
(\mathrm{LUC}, \text { this study }) \\
=88.6\end{array}$ \\
\hline
\end{tabular}


Table 11. Comparison of other Biofuels LUC results with the current study

\begin{tabular}{lll}
\hline Study $\quad$ Crop type $\quad$ Fuel product & LUC type & LUC Emissions Value \\
& $\left(\mathrm{g} \mathrm{CO}_{2 \mathrm{eq}} / \mathrm{MJ}\right.$ fuel $)$
\end{tabular}

\begin{tabular}{|c|c|c|c|c|}
\hline Fritsche et al. & Wheat & Ethanol & Direct & 25 \\
\hline & Corn & Ethanol & Direct & 18 \\
\hline & Sugarcane & Ethanol & Direct & 20 - 94 (grassland - forest) \\
\hline & Rapeseed & Biodiesel & Direct & 35 \\
\hline & Soybean & Biodiesel & Direct & 28 - 169 (grassland - forest) \\
\hline & Oil palm & Biodiesel & Direct & $-27-163$ (grassland - forest) \\
\hline Plevin et al. 2015 & Soybean & Biodiesel & Indirect & $25-38$ \\
\hline Taheripour and & Corn & Ethanol & Indirect & $12.9-22.6$ \\
\hline & Corn stover & Ethanol & Indirect & $-1.6--0.9$ \\
\hline & Miscanthus & Ethanol & Indirect & $5.8-32.3$ \\
\hline & Switchgrass & Ethanol & Indirect & $20.3-74$ \\
\hline Dunn et al. 2013 & Corn & Ethanol & Both & $4.7-11$ \\
\hline & Corn stover & Ethanol & Both & -1.2 \\
\hline & Miscanthus & Ethanol & Both & $-10--2.1$ \\
\hline & Switchgrass & Ethanol & Both & $2.7-19$ \\
\hline This Study & Algae & Renewable Diesel & Direct & 24.7 \\
\hline
\end{tabular}


Studies of this nature require incorporating a great deal of data and assumptions that make generalizations about a wide range of landscapes and operations. To illustrate the impact that uncertainty in key input data and assumptions may have on overall study conclusions, a tornado plot is shown in Figure 4. Each of the input assumed values shown in Figure 4 was varied in turn by $+10 \%$ and $-10 \%$, and the resulting percentage change in the overall baseline result (24.7 $\left.\mathrm{g} \mathrm{CO}_{2 \mathrm{eq}} / \mathrm{MJ} \mathrm{RD}\right)$ was plotted. Algae biomass yield had the largest impact on the overall result, which makes sense because this data influences everything in the renewable diesel yield used to normalize the GHG emissions. The same result would also be reached if the algae oil yield, or fuel conversion yield was also modified by $10 \%$, so 'Algae biomass yield' in Figure 4 can be thought of as a stand-in for any of these key metrics of algae fuel output from the system. Percent of carbon in biomass was held constant at $47 \%$ throughout the study, and this also is shown to have a large impact on study results. The baseline study assumption that $90 \%$ of forest biomass carbon removed for algae raceway conversion is emitted as $\mathrm{CO}_{2}$ over the lifetime of the facility is also a factor that has a large influence on the overall study results, and this is certainly a factor that should be studied in more detail for site-specific studies or IPCC Tier II / III estimates. To illustrate the impact of uncertainty in IPCC soil carbon, each baseline value for individual climate/soil regions shown in Table 1 was varied by $+10 \%$ or minus $10 \%$ at the same time. This was also the procedure to illustrate the uncertainty in grassland biomass, forestland biomass, and cropland biomass. The standard $10 \%$ change produced negligible effects on the overall baseline result for grassland or cropland biomass variables, but changing the forestland biomass estimates by $10 \%$ induced a change of $\sim 7 \%$ in the overall baseline result. 


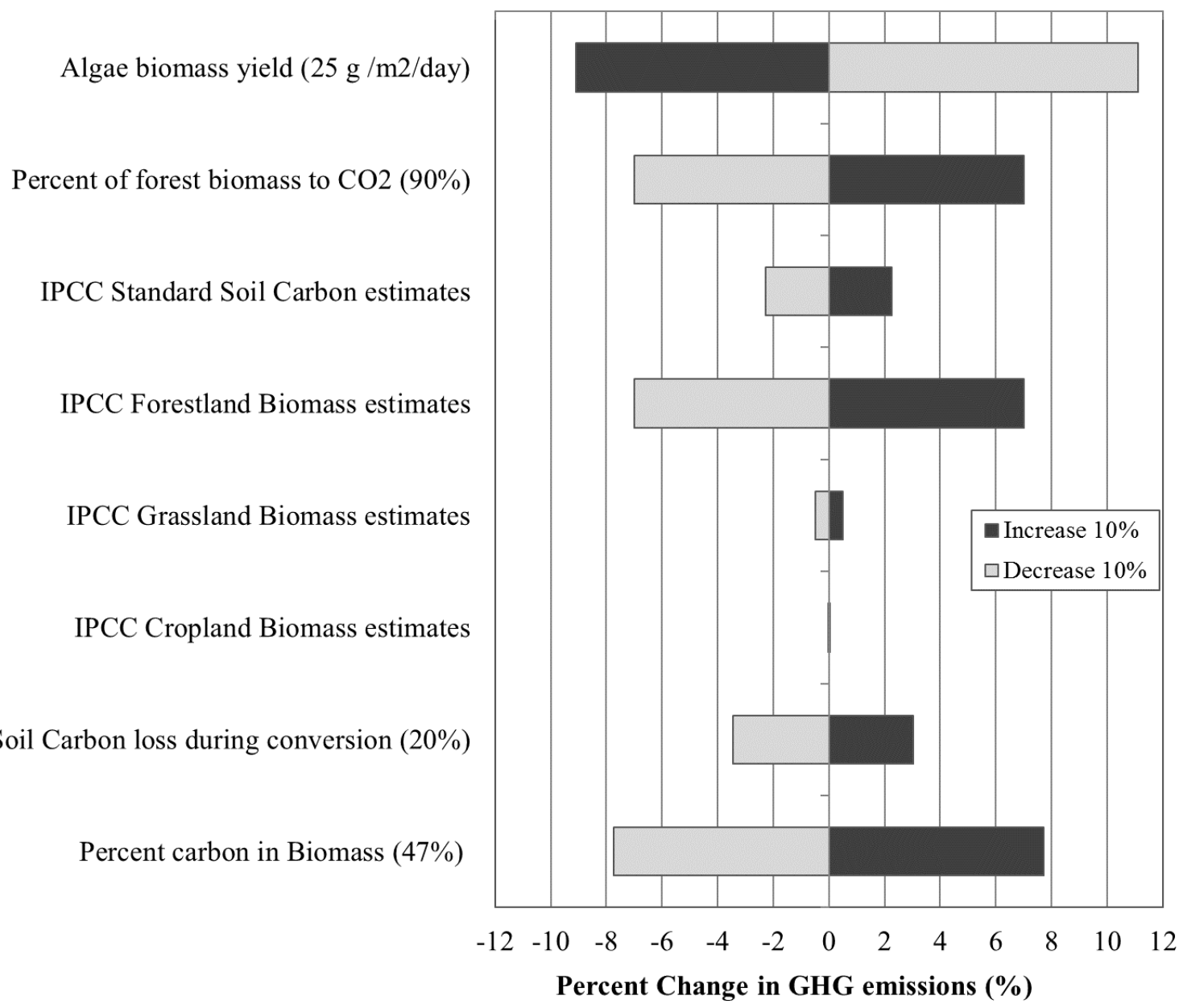

Figure 4. Tornado plot indicating the effect of a $10 \%$ increase or decrease in the baseline values of key assumptions. Where possible, the baseline assumed value is indicated in parentheses next to the name of the item. 


\section{Conclusions}

Several aspects of this dataset and study are worth considering in future research and implementation of algae biofuels facility. It does appear that LUC is worth considering in algal cultivation systems, with average $\mathrm{CO}_{2}$ emissions of between 4 and $8 \mathrm{~g} \mathrm{CO}_{2 \mathrm{eq}}$ / MJ for grasslands and croplands, roughly 6-12\% of the baseline algae fuels life cycle emissions result without considering LUC. If forestland is cleared prior to construction of algae raceways, the LUC GHG emissions penalty associated with that activity could be over $40 \mathrm{~g} \mathrm{CO}_{2 \mathrm{eq}} / \mathrm{MJ}$, larger than a resource-intensive unit operation in the algae fuels life cycle, such as dewatering, making this an extremely important focus area for reducing the burdens of this alternative fuel pathway. According to land resource assessment activity of other research teams, a large number of the sites under serious consideration are classified as 'forestland' (36\%), although this classification may reflect only the dominant land use and the area may be a patchwork of forest and other land classes. LUC GHG emissions for all of the potential sites under consideration by the expert teams in ANL et al. (2012) would be almost $25 \mathrm{~g} \mathrm{CO}_{2 \mathrm{eq}} / \mathrm{MJ}$, a level that would make it extremely difficult for the cradle-to-grave GHG emissions of algae fuels to achieve a 50\% reduction compared to fossil petroleum fuels, which is a commonly-considered target based on federal regulatory guidance in the United States.

Future studies should focus on collecting site-specific data on algal cultivation systems before and after construction to verify the Tier 1 estimates used here, and should also seek to incorporate additional land use change implications that may alter local or regional environmental parameters, such as albedo changes. It is also true that improvements in algae cultivation such as increases in algal biomass productivity or oil yield from algae which have been demonstrated in the industry, the total amount of fuel being produced in a given area of land will increase, which will have the effect of decreasing LUC emissions per MJ of final fuel product. 


\section{Acknowledgements}

The authors would like to acknowledge funding of this work by the US Department of Energy under contract DE-EE0003046 awarded to the National Alliance for Advanced Biofuels and Bioproducts. 


\section{References}

Aguilar, F., Garrett, H., 2009. Perspectives of woody biomass for energy: survey of state foresters, state energy biomass contacts, and National Council of Forestry Association executives. J. Forest. 107, 297306.

ANL, NREL, PNNL, 2012. Renewable diesel from algal lipids: An integrated baseline for cost, emissions, and resource potential from a harmonized model., ANL/ESD/12-4, NREL/TP-5100-55431, PNNL-21437. Argonne, IL: Argonne National Laboratory; Golden, CO: National Renewable Energy Laboratory; Richland, WA: Pacific Northwest National Laboratory.

ANL, 2014. The Greenhouse Gases, Regulated Emissions, and Energy Use in Transportation (GREET) Model, Argonne National Laboratory, U.S. Department of Energy.

Bennion, E.P., Ginosar, D.M., Moses, J., Agblevor, F., Quinn, J.C., 2015. Lifecycle assessment of microalgae to biofuel: Comparison of thermochemical processing pathways. Appl. Energy 154, 10621071.

Brentner, L.B., Eckelman, M.J., Zimmerman, J.B., 2011. Combinatorial life cycle assessment to inform process design of industrial production of algal biodiesel. Environ. Sci. Technol. 45, 7060-7067.

Carlsson, A.S., Beilen, J.v., Möller, R., Clayton, D., 2007. Micro- and macro-algae: utility for industrial applications. University of York.

Chen, M., Ma, L.Q., 2001. Taxonomic and geographic distribution of total phosphorus in florida surface soils. Soil Sci. Soc. Am. J. 65, 1539-1547.

Chisti, Y., 2007. Biodiesel from microalgae. Biotechnol. Adv. 25, 294-306.

Clarens, A.F., Nassau, H., Resurreccion, E.P., White, M.A., Colosi, L.M., 2011. Environmental impacts of algae-derived biodiesel and bioelectricity for transportation. Environ. Sci. Technol. 45, 7554-7560.

Dunn, J.B., Mueller, S., Kwon, H.Y., Wang, M.Q., 2013. Land-use change and greenhouse gas emissions from corn and cellulosic ethanol. Biotechnol. Biofuels 6, 51.

Frank, E.D., Han, J., Palou-Rivera, I., Elgowainy, A., Wang, M.Q., 2011. Life-Cycle Analysis of Algal Lipid Fuels with the GREET Model. Argonne National Laboratory.

Fritsche, U.R., Sims, R.E.H., Monti, A., 2010. Direct and indirect land-use competition issues for energy crops and their sustainable production - an overview. Biof. Bioprod. and Bior. 4, 692-704.

Georgianna, D.R., Mayfield, S.P., 2012. Exploiting diversity and synthetic biology for the production of algal biofuels. Nature 488, 329-335.

Haag, W.R., Mill, T., 1987. Direct and indirect photolysis of water-soluble azodyes: Kinetic measurements and structure-activity relationships. Environ. Toxicol. Chem. 6, 359-369.

Handler, R.M., Canter, C.E., Kalnes, T.N., Lupton, F.S., Kholiqov, O., Shonnard, D.R., Blowers, P., 2012. Evaluation of environmental impacts from microalgae cultivation in open-air raceway ponds: 
Analysis of the prior literature and investigation of wide variance in predicted impacts. Algal Res. 1, 8392.

Hannon, M., Gimpel, J., Tran, M., Rasala, B., Mayfield, S., 2010. Biofuels from algae: challenges and potential. Biofuels 1, 763-784.

IPCC, 2006a. 2006 IPCC Guidelines for National Greenhouse Gas Inventories, Prepared by the National Greenhouse Gas Inventories Programme, Eggleston H.S., Buendia L., Miwa K., Ngara T. and Tanabe K. (eds). Published: IGES, Japan.

IPCC, 2006b. 2006 IPCC Guidelines for National Greenhouse Gas Inventories. 4: Agriculture, Forestry and Other Land Use. Chapter 1: Introdution. Available at: http://www.ipcc-

nggip.iges.or.jp/public/2006gl/pdf/2004_Volume2004/V2004_2001_Ch2001_Introduction.pdf.

IPCC, 2006c. 2006 IPCC Guidelines for National Greenhouse Gas Inventories. 4: Agriculture, Forestry and Other Land Use. Chapter 2: Generic Methodologies Applicable to Multiple Land-Use Categories. Available at: http://www.ipcc-nggip.iges.or.jp/public/2006gl/pdf/4_Volume4/V4_02_Ch2_Generic.pdf.

IPCC, 2006d. 2006 IPCC Guidelines for National Greenhouse Gas Inventories. 4: Agriculture, Forestry and Other Land Use. Chapter 3: Consistent Representation of Lands. Available at: http://www.ipccnggip.iges.or.jp/public/2006gl/pdf/4_Volume4/V4_03_Ch3_Representation.pdf.

IPCC, 2006e. 2006 IPCC Guidelines for National Greenhouse Gas Inventories. 4: Agriculture, Forestry and Other Land Use. Chapter 6: Grassland. Available at: http://www.ipccnggip.iges.or.jp/public/2006gl/pdf/4_Volume4/V4_06_Ch6_Grassland.pdf.

IPCC, 2006f. 2006 IPCC Guidelines for National Greenhouse Gas Inventories. 4: Agriculture, Forestry and Other Land Use. Chapter 5: Cropland. Available at: http://www.ipccnggip.iges.or.jp/public/2006gl/pdf/4_Volume4/V4_05_Ch5_Cropland.pdf.

IPCC, 2006g. 2006 IPCC Guidelines for National Greenhouse Gas Inventories. 4: Agriculture, Forestry and Other Land Use. Chapter 4: Forest Land. Available at: http://www.ipccnggip.iges.or.jp/public/2006gl/pdf/4_Volume4/V4_04_Ch4_Forest_Land.pdf.

Kim, H., Kim, S., Dale, B.E., 2009. Biofuels, land use change, and greenhouse gas emissions: Some unexplored variables. Environ. Sci. Technol. 43, 961-967.

Laha, S., Luthy, R.G., 1990. Oxidation of aniline and other primary aromatic amines by manganese dioxide. Environ. Sci. Technol. 24, 363-373.

Langholtz, M., Plate, R., Monroe, M. 2015. Wood to Energy: Sources and Supply. University of Florida IFAS Extension, Wood to Energy, Circular 1526. Available at:

http://edis.ifas.ufl.edu/topic_series_wood_to_energy

Lardon, L., Hélias, A., Sialve, B., Steyer, J.-P., Bernard, O., 2009. Life-cycle assessment of biodiesel production from microalgae. Environ. Sci. Technol. 43, 6475-6481.

Mata, T.M., Martins, A.A., Caetano, N.S., 2010. Microalgae for biodiesel production and other applications: A review. Renew. Sustainable Energy Rev. 14, 217-232. 
Orfield, N.D., Levine, R.B., Keoleian, G.A., Miller, S.A., Savage, P.E., 2015. Growing algae for biodiesel on direct sunlight or sugars: a comparative life cycle assessment. ACS Sustain. Chem. Eng. 3, 386-395.

Parton, W.J., Scurlock, J.M.O., Ojima, D.S., Gilmanov, T.G., Scholes, R.J., Schimel, D.S., Kirchner, T., Menaut, J.C., Seastedt, T., Garcia Moya, E., Kamnalrut, A., Kinyamario, J.I., 1993. Observations and modeling of biomass and soil organic matter dynamics for the grassland biome worldwide. Global Biogeochem. Cycles 7, 785-809.

Passell, H., Dhaliwal, H., Reno, M., Wu, B., Amotz, A.B., Ivry, E., Gay, M., Czartoski, T., Laurin, L., Ayer, N., 2013. Algae biodiesel life cycle assessment using current commercial data. J. Environ. Manage. 129, 103-111.

Plevin, R.J., Beckman, J., Golub, A.A., Witcover, J., O’Hare, M., 2015. Carbon accounting and economic model uncertainty of emissions from biofuels-induced land use change. Environ. Sci. Technol. 49, 26562664.

Pulz, O., 2001. Photobioreactors: production systems for phototrophic microorganisms. Appl. Microbiol. Biotechnol. 57, 287-293.

Qiang, H., Guterman, H., Richmond, A., 1996. Physiological characteristics of spirulina platensis (cyanobacteria) cultured at ultrahigh cell densities. J. Phycol. 32, 1066-1073.

Quinn, J.C., Smith, T.G., Downes, C.M., Quinn, C., 2014. Microalgae to biofuels lifecycle assessmentmultiple pathway evaluation. Algal Res. 4, 116-122.

Resurreccion, E.P., Colosi, L.M., White, M.A., Clarens, A.F., 2012. Comparison of algae cultivation methods for bioenergy production using a combined life cycle assessment and life cycle costing approach. Bioresour. Technol. 126, 298-306.

Searchinger, T., Heimlich, R., Houghton, R.A., Dong, F., Elobeid, A., Fabiosa, J., Tokgoz, S., Hayes, D., $\mathrm{Yu}, \mathrm{T} .-\mathrm{H} ., 2008$. Use of U.S. Croplands for biofuels increases greenhouse gases through emissions from land-use change. Science 319, 1238-1240.

Skog, K. E., \& Nicholson, G. A. 1998. Carbon cycling through wood products: the role of wood and paper products in carbon sequestration. Forest Prod. J., 48(7/8), 75.

Smith, J.E., Heath, L.S., Skog, K.E., Birdsey, R.A., 2006. Methods for calculating forest ecosystem and harvested carbon with standard estimates for forest types of the United States. United States Department of Agriculture. Forest Service. Northeastern Research Station.

Stephenson, A.L., Kazamia, E., Dennis, J.S., Howe, C.J., Scott, S.A., Smith, A.G., 2010. Life-cycle assessment of potential algal biodiesel production in the United Kingdom: a comparison of raceways and air-lift tubular bioreactors. Energy \& Fuels 24, 4062-4077.

Stone, A.T., 1987. Reductive dissolution of manganese(III/IV) oxides by substituted phenols. Environ. Sci. Technol. 21, 979-988.

Tyner, W.E., 2013. Induced land use emissions due to first and second generation biofuels and uncertainty in land use emission factors. Economics research international 2013. 
Wigmosta, M.S., Coleman, A.M., Skaggs, R.J., Huesemann, M.H., Lane, L.J., 2011. National microalgae biofuel production potential and resource demand. Water Resour. Res. 47.

Woertz, I.C., Benemann, J.R., Du, N., Unnasch, S., Mendola, D., Mitchell, B.G., Lundquist, T.J., 2014. Life cycle GHG emissions from microalgal biodiesel-a CA-GREET model. Environ. Sci. Technol. 48, 6060-6068.

U.S. EPA, 2016. Inventory of U.S. Greenhouse Gas Emissions and Sinks: 1990-2014. Chapter 6: Land Use, Land-Use Change, and Forestry. U.S. Environmental Protection Agency. 